\title{
12 \\ Lost in translation: A semantic analysis of no da in Japanese
}

Yuko Asano-Cavanagh

\section{Introduction}

The Japanese expression no da(のだ, as well as its variants $n$ da んだ and no $の)$ is frequently used at the end of a sentence and it adds a nuance to the statement (Alfonso 1966). Syntactically, no da consists of the nominalising particle no and the copulative $d a$, and no da roughly corresponds to it is a fact that (Aoki 1986), or it is that in English (Kuno 1973a; Noda 1997). A translation of no da is commonly considered untranslatable or unnecessary when converting text from Japanese into English. For example (Yoshimoto 1988: 180; translated by Backus 1993: 121):

（1）いつか冬の日、等が言つた「「弟がいるんだけどさ、柊っていうん だ。」

'One winter day Hitoshi had said, "I have a younger brother. His name is Hiiragi."”

In (1), a man is stating the fact that he has a younger brother and his name is Hiiragi. $N d a$ (んだ) appears twice in the original Japanese; however, the meaning is not expressed at all in the English translation of the text. Although $n d a$ is lost in translation, these utterances in Japanese without $n d a$ would indisputably sound unnatural. As a consequence, it can be 
assumed that $n d a$ in Japanese has a significant, definable meaning and relevance. The following example is also worthy of consideration and supports this idea. In this example, the speaker is attempting to motivate or encourage someone: ${ }^{1}$

\section{しつかりするんだ! \\ 'Pull yourself together!'}

$N d a$ is used in giving a command to the listener, and without $n d a$, the utterance in (2) would not convey the same meaning. As Wierzbicka (2003) and Wong (2004) state, the meaning of particles is crucial to the interaction between interlocutors. Particles 'express the speaker's attitude towards the addressee, or towards the situation spoken about, his assumptions, his intentions, his emotions' (Wierzbicka 2003: 341). The meaning of a particle can be so subtle that the intended proposition would not significantly differ, in a practical sense, with or without the particle being used. Notwithstanding this, however, mastering the meaning and function of particles significantly enhances a speaker's ability to communicate. ${ }^{2}$ In fact, in the field of teaching Japanese, several error analyses have been carried out regarding no $d a$, indicating that the expression is a difficult but crucial form to understand and master for learners of Japanese (McGloin 1984; Koganemaru 1990).

There are a considerable number of studies dedicated to clarifying the meaning of no da (e.g. Alfonso 1966; Kuno 1973a, 1973b; McGloin 1984; Koganemaru 1990; Tanomura 1990; Maynard 1992; Noda 1993, 1997; Najima 2007). The research here mentioned has helped to define the function of no da. However, from a semantic point of view, the definitions are inadequate. They do not comprehensively articulate the exact meanings of no da, as they equally apply to other particles. This study uses the Natural Semantic Metalanguage (NSM) approach (Wierzbicka 1986, 2003, 2006, 2010; Goddard and Wierzbicka 1994, 2002; Goddard 1998; Peeters 2006) to examine the semantics of no da, using examples found in newspaper articles, tweets, blogs and translated texts. As a full study of no $d a$ including its variants lies outside the scope of this study, this chapter will focus on the semantics of no da, which are considered to represent an 'explanation' (Alfonso 1966; Kuno 1973a, 1973b), or to indicate the

\footnotetext{
1 seiga.nicovideo.jp/seiga/im5830462 (2016).

2 It has been pointed out that the misuse of particles could be considered a reflection of the speaker's lack of communicative skills rather than as a grammatical mistake (Wong 2004; Saigo 2011).
} 
speaker's mood (Koganemaru 1990; Noda 1993, 1997). The following section includes an examination of studies that have elaborated on the use of no da in a variety of contexts, shedding light on the above mentioned uses of no da. This is followed by a practical application of the NSM framework, which will clarify two distinct meanings expressed by no da.

\section{Previous research on no da}

\subsection{Arguments in previous research}

Among the previous analyses on the meanings of no da, Kuno (1973a, 1973b), Noda (1993, 1997) and Najima's studies (2007) are particularly noteworthy as they were detailed investigations that greatly helped in clarifying the functions and meanings of no da. First, Kuno (1973a, 1973b) states that no da is used to offer an 'explanation' for something the speaker has said or done, or for a state or condition (1973b: 144):

（3）風邪を引きました。雨に濡れたんです。

'I have caught a cold. I got wet in the rain.'

（4）体重が10ポンド減りました。病気なのです。

'I have lost 10 pounds. I am sick.'

No da in (3) indicates that 'the explanation for catching a cold is that I got wet in the rain'. In (4) no da means that 'the explanation for losing 10 pounds is that I am sick'. In both examples, the explanation is also the cause or reason for the preceding situation, and the meaning is almost the same as 'I have caught a cold. It is because I got wet in the rain', or 'I have lost 10 pounds. It is because I am sick'. However, Kuno also states that there is another usage of no da, which cannot be paraphrased with 'it is because'. Kuno instead, uses the term 'evidence', as demonstrated in the following example (1973a: 226):

（5）病気です。体重が10ポンド減つたのです。

'I am sick. The evidence for my being sick is that I have lost 10 pounds.' 
（6）僕は馬鹿です。いら勉強してもダメなのです。

'I am a fool. The evidence for my being a fool is that I am no good however hard I may study.'

Kuno argues that 'losing 10 pounds' is presented as evidence for 'being sick'; and 'being no good however hard I may study' is given as evidence for 'being a fool'.

Next, Noda $(1993,1997)$ points out that no da should be classified into two categories, depending on the existence of a listener. In examples (7) and (8) below, no da indicates that one has just grasped or come to understand an aspect of a situation. In these examples the speakers are speaking inwardly; therefore, it does not matter if a listener is or is not present to hear or witness the utterances (Noda 1997: 67):

（7）山田さんが来ないなあ。きっと用事があるんだ。

'Mr. Yamada has not come. Surely he must have something to do.'

（8）そうか、このスイッチを押すんだ。

'Oh, I see. I just need to press this switch.'

In (7), no $d a$ relates a preceding context and the resultant situation. Thus, no $d a$ in this context is called 'relating no $d a$ ' (1997: 71). Here no da implies that the speaker has understood the situation that 'Mr Yamada has something to do', as the reason or explanation for the preceding context that 'Mr Yamada has not come'. In contrast, in example (8), no da is used but does not connect two separate situations or contexts. Thus, (8) is considered an example of 'unrelating no da' (1997: 71). Rather, no da here indicates that one has just grasped or come to understand that 'one should press the switch' as a newly perceived, stand-alone fact.

According to Noda, another function of no $d a$ is to present a listener, someone at whom or for whom the utterance is expressed, with information that the speaker had previously known but is now sharing so that the listener is also made aware. Therefore, when no $d a$ is used in this way, by definition, the existence of a listener becomes obligatory (1997: 67):

（9）僕、明日は来ないよ。用事があるんだ。

'I will not come tomorrow. I have something to do.' 
(10)

\section{このスイッチを押すんだ!}

'Press this switch!'

No da in (9) directly associates one idea with another and therefore it is regarded as 'relating no $d a$ '. It expresses the speaker's wish to inform the listener of a situation $Q$ (e.g. 'I have something to do'), of which the speaker presumes the listener was not aware. By providing information to the listener about a situation $Q$, no da facilitates the listener's understanding of the situation $P$ (e.g. 'I will not come tomorrow'). In contrast, no da in (10) does not make a connection between two concepts and it is therefore an example of 'unrelating no da'. No da here indicates the speaker's desire that the listener perceives whatever it is that, in the speaker's mind, is an established fact. This usage can often be observed when someone is giving an order or confession and it adds emphasis to the phrase being spoken.

Finally, it is worth considering Najima's detailed analysis of no da from the perspective of Relevance Theory (Sperber and Wilson 1986). Najima (2007) says that the interpretation of no da depends primarily on the speaker's intention. Najima argues that no $d a$ has only one basic function: one intentionally and explicitly presents a listener with a proposition-a proposition interpreted from the listener's point of view. This point is illustrated well by the example below, where no $d a$ is a crucial component of the utterance, without which the sentence in Japanese would be nonsensical. Suppose that a student, who has arrived late for class, makes the following utterance to their teacher (Najima 2007: 61):
(11) a.
犬のポチがご飯を食べなかったんです。
'My dog Pochi didn't eat his food.'
b. ?犬のポチがご飯を食べませんでした。
'My dog Pochi didn't eat his food.'

The utterance (11b) without no da is, as a result, not appropriate, natural or sensical in the aforementioned context. This is because, "being late for class' and 'the fact that the dog did not eat his food' are not concepts that have an obvious cause and effect relationship. By using no da, the utterance can imply the speaker's intention to convey a proposition to the listener and can therefore be interpreted as a reason for the situation; that is, being late. No $d a$, in this context, indicates that the speaker is inferring that there is a connection between the proposition and the context wherein the 
utterance is being made. Najima argues that the various functions, such as 'explanation', 'recognition', 'order', or 'emphasis', are the derivatives of this basic function of no da.

\subsection{Inadequacies of previous research}

Previous attempts to provide definitions of no da offer some general explanations for its usage. However, these definitions are inaccurate as they do not clarify the subtle semantic differences between no $d a$ and other particles in Japanese (especially in situations where the translations into English would be the same).

First, no da is considered to possess the function of giving an 'explanation' (Kuno 1973a, 1973b). As argued by many (e.g. Tanomura 1990), the term 'explanation' is problematic, since there are various cases where it does not apply, such as when the speaker is giving an order or instruction. Second, Noda (1997) argues that a function of no da is to indicate that one has newly ascertained a concept or situation. However, this claim is also flawed, as this function is not only expressed by no $d a$, but also communicated by other particles in Japanese. Consider the following utterance where someone has just experienced an earthquake: ${ }^{3}$

\section{うわ!地震だわ。}

'Oh my! An earthquake ...'

It is well recognised (e.g. Hattori 1993; Washi 1997) that the sentencefinal particle $w a(わ)$ is often used with a falling intonation, by both male and female speakers, when the speaker has come to newly appreciate or perceive something. Likewise, the sentence-final particle $k a$ (か) has a similar function (Moriyama 1992). See the following example, where a woman has just realised that Christmas is coming very soon: ${ }^{4}$

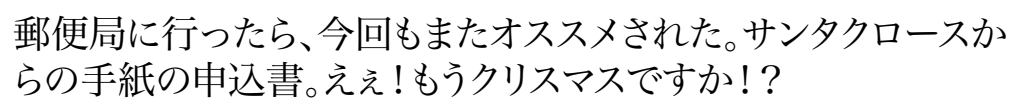

郵便局に行ったら、今回もまたオススメされた。サンタクロースか らの手紙の申込書。ええ!もうクリスマスですか!?

'When I went to the post office, they gave me the application form for a letter from Santa Claus. Wow! Is it Christmas already!?’

3 ameblo.jp/mimizuku-cafe/entry-12252046129.html (2017).

4 ameblo.jp/moji-moji-tsushinkyoku/entry-12312648949.html (2017). 
In this way, the sentence-final particle $k a($ ( ) is used when the speaker has come to appreciate something new.

According to Noda (1997), another function of no da is to present the listeners with information of which they were not previously aware. However, the sentence-final particle yo (よ) has a similar function, as demonstrated by the following example: ${ }^{5}$

\section{明日香レンタサイクル 観光に便利ですよ。}

'Asuka bicycle hiring service. It's convenient for sightseeing.'

In (14), a traveller who hired a bicycle for sightseeing is informing other tourists that it is convenient. Yo (よ) is used to inform readers who may be looking for information or a recommendation. In (14), no da could also be used. One may therefore ask what the difference would be between using no da and yo in this context. This point will be discussed in section 3.1.1. Finally, there is a point that contradicts the claim that the function of no $d a$ is to intentionally and explicitly present the listener/s with a proposition (Najima 2007). In the following example an office worker has just learned about business etiquette: ${ }^{6}$

\section{へ〜そうなんだ!社会人になって初めて知ったビジネスマナー}

'Oh, that's how it is! Business etiquette which I have only come to know after starting work.'

In (15), the office worker is talking inwardly to herself. $N o d a$, in this context, is not being used by the speaker to convey information to someone else. The meaning of no da in this case does not include one's intention to convey information to the listener/s. Thus, it is not reasonable to claim that the main function of no da is to present the listener/s with a proposition intentionally and explicitly. In summary, the definitions provided by previous research are descriptively inconclusive and inaccurate. Although there have been detailed investigations into the functions of no da, the explanations can apply to the usage of sentence-final particles such as $w a$, $k a$ and $y o$, and therefore ambiguity remains. In order to define the subtle

5 www.jalan.net/kankou/spt_29402ee4590068726/kuchikomi/0003875770/ (2016).

6 woman.mynavi.jp/article/150406-10/ (2018). 
meanings of no $d a$, this study utilises the NSM method and proposes two definitions for no $d a$. The proposed explications apply exclusively to no $d a$ and explain the core usages of no da.

\section{Analysis of no da}

\subsection{Two meanings of no da}

As Noda (1997) points out, there is considerable value in making a distinction between two uses of no $d a$ : where no da is directed to the listener/s (no da ); and where no da can be used with or without a listener or listeners $\left(n o d a_{2}\right)$. The distinction is an important component of the analysis, since the meaning of no da is slightly different depending on whether the existence of a listener is required. Therefore, two explications of no da will be proposed here using semantic primes.

\subsubsection{No da as used when directed towards a listener: no da}

First, no $d a$ is used when the speaker addresses a listener or listeners (no $d a_{1}$ ). Its function is considered to be to provide an 'explanation' (e.g. Kuno 1973a, 1973b). In the following example, no $d a_{1}$ gives background information by connecting two contexts (Yoshimoto 1990: 203; translated by Sherif 1994: 177):

(16) 咲いないよ。旅行に行ったんだ。

'Saki's not here. She went on a trip.'

7 See below for examples of NSM explications defining the sentence-final particles $w a, k a$ and $y o$ (Asano 2004):

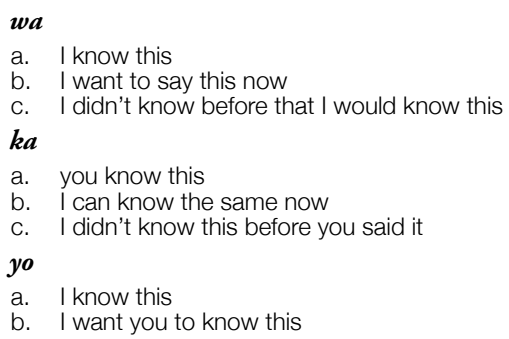


By using $n d a$, the speaker is stating that 'Saki went on a trip', which led to the present condition that 'she is not here now' (Noda 1997: 91-95). $N d a$ is necessary, as it links two separate pieces of information. In short, the speaker is attempting to help the listener understand the situation by adding supplementary information. Note that the existence of a listener or listeners is obligatory for this usage. Without the listener, the use of no da would sound awkward. Maynard (1992) also suggests that no $d a$ functions as a 'marker of conscious mention'. It is therefore possible to deduce that no da in this situation expresses the speaker's desire to convey information to the listener by linking two pieces of information, indicating 'I want to say something X about something Y to you; I say: it is like this; I can say it because I know it'.

Noda (1997: 71) classifies no da into two categories: 'relating no da' and 'unrelating no da'. Example (16) is a typical example of 'relating $n o d a$ '. However, the difference between 'relating no $d a$ ' and 'unrelating no $d a$ ' is simply whether or not there is a preceding context, and there does not seem to be any observable semantic difference between them. Consider the following example of no $d a_{1}$, which is used when the speaker addresses a listener, but does not connect two contexts (unrelating no $d a$ ). In (17), a young man is making a phone call to his friend at midnight (Yoshimoto 1988: 70; translated by Backus 1993: 45):

$$
\begin{aligned}
& \text { 「あいつはちゃんと、戦つて死んだんだよ。」雄一はいきなりそう } \\
& \text { 言つた。 }
\end{aligned}
$$

“'She died fighting." Yuichi said without preamble.'

In (17), a young man is talking to his friend on the phone and bluntly states that his mother had died. By using no $d a_{1}$, the speaker attempts to convey the information to the listener, indicating 'I want to say something $\mathrm{X}$ about something Y to you; I say: it is like this; I can say it because I know it'. No $d a_{1}$ represents the speaker's wish to give a piece of information to the listener, and it does not matter whether there is any preceding context. The following example also demonstrates this definition. In (18), someone who previously studied in New Zealand is recommending the country as the ideal destination for study abroad to readers of the website: ${ }^{8}$ 
(18) ニュージーランド、留学するなら断然オススメの国なんです!!

'New Zealand is highly recommended for study abroad!'

In (18) also, no $d a$ indicates the speaker's desire to give readers information, which can be paraphrased as 'I want to say something $\mathrm{X}$ about something Y to you; I say: it is like this; I can say it because I know it'. There is no significant semantic difference between relating no $d a$ and unrelating no da. Now recall that no da is often used in relaying the speaker's decision or when giving an order to a listener. For instance: ${ }^{1}$

今度 東京へ行くんですが 東京駅から月島まで一番簡単な
ルート教えてもらえませんか

'I am going to Tokyo. Could anyone tell me the easiest way to get from Tokyo to Tsukishima station?’

(20) 頑張るんだよ!応援しているからね!

'Do your best! I am rooting for you!'

In (19), a man is seeking advice on how to get from Tokyo to Tsukishima station. Although this is not an established fact in the speaker's mind, the man declares his decision, indicating 'I can say it because I know it'. Similarly, in (20), someone is encouraging a sports team to do their best. Here no da is indicating that, by presenting an action that the speaker believes the listener should perform, the speaker wants to urge the listener to do something. ${ }^{10}$ That is, the speaker is declaring that she knows the action will be done in the future, stating that 'I can say it because I know it'. This is how no da qualifies as a command.

Noda (1997) claims that the speaker gives the information that the listener has not previously recognised. It is true that the no da may connote that the information is new to the listener. In fact, the use of no da becomes somewhat inappropriate in situations where the listener shares the same information. ${ }^{11}$ However, it is questionable whether no $d a$ includes the

9 (19): oshiete.goo.ne.jp/qa/6211711.html (2010); (20): twitter.com/hashtag/\%E9\%A0\%91\% Е5\%BC\%B5\%Е3\%82\%8B\%E3\%82\%93\%Е3\%81\%A0\%E3\%82\%88 (2018).

10 Note that no da used in giving an order is different from an imperative form (頑張れ!) which signifies 'I want you to do it'.

11 As commonly noted (e.g. Maynard 1992), the sentence-final particle $n e$ is usually used to signal that the information is equally shared between the speaker and the listener. 
speaker's assumption regarding the listener's stance or previous knowledge. Recall example (1) (Yoshimoto 1988: 180; translated by Backus 1993: 121):

\section{（1）いつか冬の日、等が言つた。「弟がいるんだけどさ、柊っていうん だ。」}

'One winter day Hitoshi had said, "I have a younger brother. His name is Hiiragi.",

In (1), a man is stating the fact that he has a younger brother and his name is Hiiragi. So, does $n d a\left(n o d a_{1}\right)$ here signify that the speaker has made a presumption about the listener's previous knowledge, indicating 'I think: you don't know this', or 'I want you to know this'? Actually, it does not. Although the presence of a listener is obligatory, no da does not infer or make any suggestion regarding the listener's epistemic stance. Using no da, Hitoshi is simply stating what he knows to be a fact, focusing on his own knowledge, while disregarding the listener's stance. This is the reason why the utterance can infer that the information is being presented to the listener as new information. On the other hand, the sentence-final particle yo implies the speaker's wish to convey new information to the listener, indicating 'I want you to know this'. As Martin (1975: 918) points out, ' $y o$ is often used in asserting a claim, advocating a course of action or emphasising a warning'. For instance, suppose that an adult sees a child playing on a busy street and cautions the child about the dangers of the traffic. Yo is thus the natural choice instead of no da in (21):

（21）a. 危ないよ。
'(Look out—) it's dangerous!'
b. ? 危ないんだ。
'It's dangerous.'

Yo (よ) clearly functions as a warning about the traffic, while $n d a$ does not, because in (21a) the particle yo insinuates the speaker is giving new information to the listener. $Y o$ is used to give the listener information perceived to be necessary, indicating 'I know this; I want you to know this' (Asano 2004). On the other hand, no da merely conveys the information ('I want to say something $\mathrm{X}$ about something $\mathrm{Y}$ to you'), and therefore the utterance does not qualify as a warning. To further illustrate this point, recall example (14) where $y o$ is used: 
(14)

明日香レンタサイクル 観光に便利ですよ。

'Asuka bicycle hiring service. It's convenient for sightseeing.'

In (14), a traveller who hired a bicycle for sightseeing is informing other tourists that it is convenient. Yo signifies the speaker's intention to tell the listener/s what the speaker knows, indicating 'I want you to know this'. This is the reason why the utterance is for the benefit of those who did not previously possess the information. It is possible to use no da instead of $y o$ in (14), however the particle will merely connote that a fact is being stated:

\section{明日香レンタサイクル 観光に便利なんです。}

'Asuka bicycle hiring service. It's convenient for sightseeing.'

By using no $d a_{1}$, the writer is simply connecting two pieces of information; Asuka bicycle service exists and it is convenient for sightseeing. Therefore, if the writer had intended to deliberately infer she was conveying new information to the viewers, she may have combined no da, with yo, as in (14) below:

(14)”明日香レンタサイクル 観光に便利なんですよ。

'Asuka bicycle hiring service. It's convenient for sightseeing.'

$N$ desu yo (んですよ or $n$ da yo んだよ) is often used in daily conversation. The combination of no $d a_{1}$ and yo signifies 'I want to say something $\mathrm{X}$ about something Y to you; I say: it is like this; I can say it because I know it; I want you to know it'.

Based on these observations, no da, which is directed to a listener, can be defined using semantic primes as follows:

\section{[A] no da}
a. I want to say something $X$ about something $Y$ to you
b. I say: it is like this
C. I can say it because I know it

Component (a) expresses the speaker's desire to portray information to the listener/s. Components (b) and (c) mean that the speaker claims that the information is factual. 


\subsubsection{No da as used with or without a listener: no $d a_{2}$}

The second meaning of no $d a$, referred to here as no da, can be used with or without the existence of a listener/s. In short, the existence of a listener is optional. There are two significant differences between no da and no $d a_{2}$. First unlike no $d a$, semantically no da does not include the component 'to you'. Second, as Noda (1997) suggests, no da signifies that the speaker has perceived something or become aware of a situation of which they (the speaker) had not previously been aware. Therefore, no $d a_{2}$ can express a speaker's new understanding or realisation. See the following: ${ }^{2}$

(22) 冷蔵庫に行こうとしたら、トイレに入ってた。疲れているんだなと 思った瞬間。

'When aiming to go to the fridge I realised I'd entered the toilet room. That was the moment $\underline{I}$ realised how tired I am.'

In (22), no da indicates that the writer, of this comment on twitter, has just realised she is tired, evidenced by the fact that she went to the toilet when intending to go to the fridge. Here, no $d a$ connotes that the speaker has just recognised something new. This can be explicated as follows: 'I know something now; because of this, I want to say something about it now; I say: it is like this'.

Noda (1997) divides no $d a_{2}$ into 'relating no $\mathrm{da}_{2}$ ' and 'unrelating no $\mathrm{da}$ '. It is true that no $d a_{2}$ can be used to connect two separate concepts (relating them to each other), as shown in (22). However, the distinction does not seem to affect the core meaning of no $d a$. Consider the following example, where no $d a_{2}$ is used without linking two separate concepts or situations: ${ }^{13}$

$$
\text { 今日って祝日だったんだ。 }
$$

'I just realised that today is a public holiday.'

In (23), the speaker just became conscious of the fact that it is a public holiday. No da is often used when one suddenly registers something; that is, suddenly becomes conscious of it. Thus, in such situations it would not

12 twitter.com/hashtag/\%E7\%96\%B2\%E3\%82\%8C\%E3\%81\%A6\%E3\%82\%8B\%E3\%82\% 93\%E3\%81\%A0\%E3\%81\%AA\%E3\%81\%A8\%E6\%80\%9D\%E3\%81\%A3\%E3\%81\%9F\%E7\% 9E\%AC\%E9\%96\%93 (2017).

13 ameblo.jp/lapi-slomaga/entry-12410469115.html (2018). 
matter whether or not there is a related statement before the utterance. In example (23), no $d a_{2}$ is used to express surprise, indicating 'I know something now; because of this, I want to say something about it now; I say it is like this'.

Similarly, no da is also used when one recollects information that had been forgotten: ${ }^{14}$

（24）結婚記念日って今日だったんだ。

'Today is our wedding anniversary.'

In (24), a woman has suddenly remembered that it is her wedding anniversary. No $d a$, in this context, connotes that the speaker has recollected something in that moment but is not making a connection between the realisation and any other idea or concept. Here, no da does signify that one has just become aware, indicating 'I know something now; because of this, I want to say something about it now; I say: it is like this'. It is reasonable to surmise that linking two unrelated contexts is not a factor in the fundamental meaning of no $d_{2}$. Judging by the analysis discussed above, the meaning of $n o d a_{2}$ can therefore be explicated as follows:

\section{[B] no da}
a. I know something now
b. because of this, I want to say something about it now
c. I say: it is like this

Components (a), (b) and (c) show one's desire to convey that one has just grasped a situation, of which one was not previously consciously aware. ${ }^{15}$ As demonstrated in the explication, no da does not involve listeners 'to you', and therefore it can be used when speaking inwardly to oneself.

14 3594-chika.jugem.jp/?eid=462599 (2018).

15 One may argue that no $d a_{2}$ represents thoughts rather than tangible knowledge. However, this perspective lacks plausibility because $n o d a$ is usually used when stating facts. In instances where the speaker shows understanding, no da ${ }_{2}$ can be combined with omou 'think': no da to omou (which would signify 'I say: I think like this; I can say it because I know something now'). 


\section{Conclusion}

This chapter examined the meanings of no da and proposed new definitions using semantic primes. This study has clarified the meaning of no da when the existence of a listener is obligatory, and when the existence of a listener is not a compulsory component. The difference between the two can subsequently be explained based on whether or not no da includes the components 'to you' and 'now':

\section{[A] no da}
a. I want to say something $X$ about something $Y$ to you
b. I say: it is like this
c. I can say it because I know it

\section{[B] no da}
a. I know something now
b. because of this, I want to say something about it now
c. I say: it is like this

One may argue that the difference between no da and no $d a$ is contextual. However, the use of no da is not natural or sensical without a listener and in contrast, no $d a_{2}$ can be used when speaking to oneself. Furthermore, the component 'now' does not apply to examples of utterances wherein no $d a$ has been used. The proposed definitions are consistently applicable to a range of usages and in a range of contexts.

This research is an example of the applicability of the NSM approach to reveal the subtleties and nuances of Japanese particles that are often lost in translation. Wierzbicka states that particles 'are what distinguishes human language from the languages of robots' (1986: 519). Wierzbicka asserts that particles 'reflect the culture of a given speech community' better than other aspects of language (2003: 341). Her statements are directly applicable to the Japanese language, as it would be nearly impossible to hold a natural conversation without particles in Japanese (Saigo 2011). If no da is absent, the utterance would indicate that the speaker is simply presenting the information mechanically, with no emotional involvement. 


\section{Acknowledgements}

I would like to express my gratitude to Zhengdao Ye and the anonymous reviewers for their comments. In addition, I would like to thank Elizabeth Miller for her assistance in editing the text.

\section{References}

Alfonso, Anthony (1966). Japanese Language Patterns Volume 1. Tokyo: Sophia University.

Aoki, Haruo (1986). Evidentials in Japanese. In Wallace. L. Chafe and Johanna Nichols (eds), Evidentiality: The Linguistic Coding of Epistemology. Norwood: Ablex Publishing Corporation, 223-38.

Asano, Yuko (2004). Semantic Analysis of Epistemic Modality in Japanese. Unpublished PhD dissertation, The Australian National University, Canberra.

Goddard, Cliff (1998). Semantic Analysis: A Practical Introduction. Oxford: Oxford University Press.

Goddard, Cliff and Anna Wierzbicka (eds) (1994). Semantic and Lexical Universals: Theory and Empirical Findings. Amsterdam: John Benjamins.

Goddard, Cliff and Anna Wierzbicka (eds) (2002). Meaning and Universal Grammar: Theory and Empirical Findings (2 vol.). Amsterdam: John Benjamins.

Hattori, Tadashi (1993). Hanseigo no shūjoshi wa ni tsuite [On the function of the general sentence-final particle wa]. Döshisha Joshi Daigaku GakujutsuKenkyü Nenpō [Annual Reports of Studies, Döshisha Women's College of Liberal Arts] 43 (4): 1-15.

Koganemaru, Harumi (1990). Sakubun ni okeru 'no da' no goyōrei-bunseki [Error analysis of no da in compositions]. Nihongo Kyöiku [Journal of Japanese Language Teaching] 71: 182-96.

Kuno, Susumu (1973a). The Structure of the Japanese Language. Cambridge, MA: MIT Press.

Kuno, Susumu (1973b). Nihon bunpō kenkyü [Studies in Japanese Grammar]. Tokyo: Taishūkan Shoten.

Martin, Samuel E. (1975). A Reference Grammar of Japanese. New Haven and London: Yale University Press. 
Maynard, K. Senko (1992). Cognitive and pragmatic messages of a syntactic choice: The case of the Japanese commentary predicate $n(0)$ da. Text 12 (4): 563-613. doi.org/10.1515/text.1.1992.12.4.563.

McGloin, Naomi Hanaoka (1984). Danwa bunshō ni okeru 'no desu' no kinō [Function of no desu in discourse]. Gengo [Language] 13 (1): 254-60.

Moriyama, Takuro (1992). Gimon-gata-jōhō-juyō-bun o megutte [On questiontype Information acceptance sentences]. Osaka Daigaku Gobun [Gobun, University of Osaka] 59: 35-44.

Najima, Yoshinao (2007). No da no imi kinō [The Meaning and Function of No Da]. Tokyo: Kuroshio Shuppan.

Noda, Harumi (1993). 'No da' to shūjoshi 'no' no kyōkai o megutte [The boundary between no da and the sentence-final particle no]. Nihongogaku [Japanese Linguistics] 12 (10): 43-50.

Noda, Harumi (1997). 'No (da)' no kinō [Functions of No Da]. Tokyo: Kuroshio Shuppan.

Peeters, Bert (ed.) (2006). Semantic Primes and Universal Grammar: Empirical Evidence from the Romance Languages. Amsterdam: John Benjamins. doi.org/ $10.1075 /$ slcs. 81 .

Saigo, Hideki (2011). The Japanese Sentence-Final Particles in Talk-in-Interaction. Amsterdam: John Benjamins.

Sperber, Dan and Deirdre Wilson (1986). Relevance: Communication and Cognition. Oxford: Blackwell.

Tanomura, Tadaharu (1990). Gendai nihongo no bunpō I- 'no da' no imi to yōhō [Modern Japanese Grammar I-The Use and Meaning of No Da]. Osaka: Izumi Shoin.

Washi, Rumi (1997). Shūjoshi to hatsuwa-ruikei-tōkyō-go shūjoshi 'wa' to 'na' no danwa ni okeru hataraki [Sentence-final particles and utterance typesthe function of $w a$ and na in Tokyo dialect]. Osaka Gaikokugo Daigaku, Nihongo Nihon Bunka Kenkyū [Studies in Japanese Language and Culture, Osaka University of Foreign Languages] 7: 65-79.

Wierzbicka, Anna (1986). Introduction. Special issue, 'Particles'. Journal of Pragmatics 10: 519-34.

Wierzbicka, Anna (2003 [1991]). Cross-Cultural Pragmatics: The Semantics of Human Interaction (2nd edn). Berlin: Mouton de Gruyter. 
Wierzbicka, Anna (2006). English: Meaning and Culture. New York: Oxford University Press.

Wierzbicka, Anna (2010). Experience, Evidence, and Sense: The Hidden Cultural Legacy of English. New York: Oxford University Press. doi.org/10.1093/ acprof:oso/9780195368000.001.0001.

Wong, Jock (2004). The particles of Singapore English: A semantic and cultural interpretation. Journal of Pragmatics 36 (4): 739-93. doi.org/10.1016/s03782166(03)00070-5.

Yoshimoto, Banana (1988). Kicchin. Tokyo: Fukutake Shoten. [English translation: Yoshimoto, Banana (1993). Kitchen. Translated by Megan Backus. London: Faber and Faber.]

Yoshimoto, Banana (1990). N.P. Tokyo: Kadokawa Bunko. [English translation: Yoshimoto, Banana (1994). N.P. Translated by Ann Sherif. London: Faber and Faber.] 
This text is taken from Meaning, Life and Culture: In conversation with Anna Wierzbicka, edited by Helen Bromhead and Zhengdao Ye, published 2020 by ANU Press, The Australian National University,

Canberra, Australia.

doi.org/10.22459/MLC.2020.12 